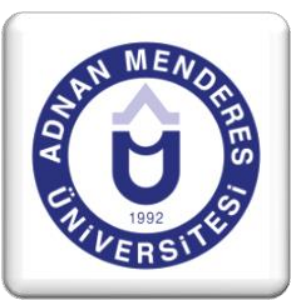

\title{
Yaşlı Yoksulluğunun Yarattığı Sosyal ve Psikolojik Sorunlar: Muğla Örneği ${ }^{1}$
}

\author{
Mevlüde TÜRKAN ${ }^{2}$, Sergender SEZER ${ }^{3}$
}

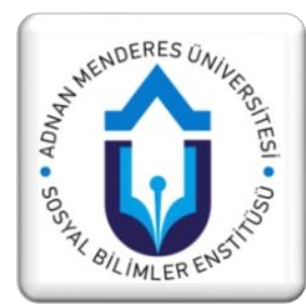

\section{ÖZET}

Bu çalışma, Muğla ilinde yaşlı nüfus oranlarının yüksek olduğu Köyceğiz, Fethiye, Menteşe ve Ortaca ilçelerinde yaşayan 65 yaş ve üstü 509 bireyle yapılan saha araştırmasının sonuçlarına dayanılarak oluşturulmuştur. $\mathrm{ADNKS}^{4}, 2016$ sonuçlarına göre, Türkiye nüfusunun \% 8,3'ünü 65 yaş ve üstü bireyler oluşturmaktadır. Araştırma evrenini oluşturan Muğla ilinde bu oran \% 11.4'tür.

Çalışma, sanayileşme, modernleşme, teknolojinin gelişmesi dolayısıyla yaşam süresinin uzaması bağlamında yaşlılığın nasıl sosyal sorun haline geldiği temelinden hareket ederek yaşli yoksulluğunun sebeplerini saptamayı amaçlamaktadır. Yaşlı yoksulluğuna yönelik geliştirilen politikalar incelenerek alternatif çözüm yolları üretmek de amaçlanmaktadır. Bildiri de oluşturulurken, "yaşlanma, fiziksel ve zihinsel faaliyetlerin yavaşladığı ve zayıfladığı bir süreç olduğundan yaşlı bireylerin ekonomik gelirleri düşmektedir”, "yaşlılıkla birlikte gelen kendine yetememe durumu ve artan sağlık ihtiyaçları yaşlı bireylerin ekonomik olarak sorunlar yaşamasına neden olur", "kır ve kentin ihtiyaçları farklıdır ve bu alanlarda yaşayan insanların ihtiyaç ve beklentileri farklı olduğundan, yoksulluk algılarında da farklılık görülür, buna göre kırda yaşayan yaşlılar daha düşük ekonomik gelire rağmen kendilerini yoksul olarak görmezken kentte yaşayan yaşlılar daha yüksek ekonomik gelire rağmen kendilerini yoksul olarak değerlendirir" varsayımları test edilmeye çalışılmıştır.

Saha araştırması sonucunda oluşturulan bu bildiri işlevselci kuram çerçevesinde tartışılarak anlamac1yorumlamacı sosyoloji yöntemiyle değerlendirilmiştir. İşlevselci kurama göre, yaşamın tüm evrelerinin bir bütün olarak ele alınması durumunda, yaş ilerledikçe bireylerin fiziksel, toplumsal ve ekonomik işlevlerinde geriye doğru bir gidiş söz konusudur. Bu nedenlerle yaşl1lık dönemine karşı oluşturulan önyargılar toplumsal bütünü bozmakta ve sistemin çözülmesine neden olmaktadır. Anlamacı-yorumlamacı yöntemsel yaklaşım ise sosyal eyleme ve toplumsal olguya vurgu yaparak onu tarihselliği ve toplumsallığı içinde anlamaya ve açıklamaya çalışır. Her olguyu ve olayı kendi toplumsal gerçekliği içinde nedensellik gözeterek yorumlamayı ve anlamayı amaçlar. Toplumsal alanda önemli bir sorun haline gelen yaşlı yoksulluğunun yarattığı sosyal ve psikolojik sorunları yaşlılık olgusunun toplumsallığı içinde, bu yönteme uygun olarak değerlendirilmiştir.

Anahtar Kelimeler; Yaşlılık, Yoksulluk, Yaşlı Yoksulluğu, Sosyal Dışlanma, Kentleşme.

\footnotetext{
${ }^{1}$ Bu bildiri, Muğla Sıtkı Koçman Üniversitesi Bilimsel Araştırma Projeleri Fonu (MSKÜ-BAP) tarafından desteleklenen 16/167 no'lu projenin sonuçlarına göre hazırlanmıştır.

${ }_{2}^{2}$ Muğla Sttkı Koçman Üniversitesi, Sosyal Bilimler Enstitüsü, Sosyoloji Anabilim Dalı, Yüksek Lisans Öğrencisi, Tel: 0539 36493 76, mevludeturkan@hotmail.com

${ }^{3}$ Muğla Sitkı Koçman Üniversitesi, Sosyoloji Bölümü Öğretim Üyesi, Tel: 05325997345 sergender@ gmail.com

${ }^{4}$ ADNKS: Adrese Dayalı Nüfus Kayıf Sistemi
} 


\section{Social and Psychological Problems Created By Elderly Poverty: Muğla Sample ${ }^{1}$} ABSTRACT

This paper is based on the results of a field research with 509 people aged 65 years or older in Köyceğiz, Fethiye, Menteşe and Ortaca counties of Muğla, where rates of elderly population is high. According to the results of ADNKS $^{2}-2016,8.3 \%$ of Turkey's population is composed of individuals aged 65 and over. In the province of Muğla, which constitutes the research universe, this rate is $11.4 \%$.

The paper aims to determine the causes of poverty among the elderly on the basis of how aging has become a social problem in the context of the increased life span resulting from industrialization, modernization and technological development. Besides, it is also aimed to produce alternative solutions by examining the policies developed for elderly poverty. While the paper is being written, the following hypotheses were tested: "As aging is a process in which physical and mental activities decline and weaken, financial incomes of elderly individuals also decrease", "Elder individuals face financial problems because of the self-insufficiency and increased healthcare needs that accompany aging", "As rural and urban areas and people who live there have different necessities and expectations, their perceptions of poverty are also different; therefore, even though urban elderly people have more income rather than rural elderly people, they see themselves as poorer and vise versa."

This paper, which was created as a result of a field research, uses functionalist theory in its discussions and interpretive sociological method in its evaluations. According to functionalist theory, when all the phases of life are taken as a whole, there is a regression in the physical, social and economic functions of the individual as the age progresses. The prejudices against the aging period based on these regressions disrupt the social whole and cause the social system to disintegrate. On the other hand, the interpretive methodological approach emphasizes social action and social facts, and tries to understand them in their historicity and social contexts. It seeks to interpret and understand every phenomenon and fact in their own social reality and causality. The social and psychological problems created by the elderly poverty, which has become an important social problem, were evaluated in accordance with this method within the social context of aging.

Key Words; Elderly, Poverty, Elderly Poverty, Social Exclusion, Urbanization.

\footnotetext{
${ }^{1}$ This paper has been prepared according to the results of the project 16/167 supported by Muğla Sttk1 Koçman University Scientific Research Projects Fund (MSKU-BAP).

${ }^{2}$ ADNKS: Address Based Population Registration System (ABPRS)
} 


\section{Giriş}

İnsanlığın varoluşundan bugüne toplumsal değişmeye neden olan çok çeşitli olaylar, buluşlar, bilimsel gelişmeler, ekonomik ve siyasi dönüşümler olmuştur. Tek başına bir olay bile çoğu zaman kapsamlı, dalga dalga yayılan ve etkisi her geçen gün artan değişimlere sebep olabilmektedir. Sanayi Devrimi bunlardan biridir. Sanayileşme, diğer onlarca farklı sebep gibi toplumun değişim ve dönüşümünü gerçekleştiren veya hızlandıran önemli etkenlerden biridir. Sanayileşme, yarattığı toplumsal değişmeyle birlikte, yine toplumsal değişimde önemli etkiye sahip olan göç ve kentleşme olgularını da beraberinde getirmektedir.

Kentsel bölgeler iş, sağlık, eğitim, ulaşım, güvenlik gibi alanlardaki gelişmişliği ile bünyesinde çekici özellikler barındırmaktadır. Kırsal bölgeler ise eğitim, iş, ulaşım, sağlık ve güvenlik alanlarının yetersizliği nedeniyle itici özellikler taşımaktadır. Kırsal bölgelerde yaşayan bireyler hizmetlerin yetersiz olması, düşük gelir ve tarımda makineleşme sonucu işsizlik problemiyle karşılaşmaları nedeniyle iş ve yaşam olanaklarının daha fazla olduğu kentlere yönelmişlerdir. Kente göç eden nüfus, çoğunlukla eğitim ve çalışma çağındaki genç nüfustur.

Özellikle çalışma çağındaki nüfusun kente göç etmesi yaşlı nüfusu iki şekilde etkilemiştir; 1. Kırsal bölgelerde kalanların ya yaşı ya da yaşlanmakta olan bireyler olması, zamanla bu bireylerin iyice yalnızlaşmaları; temel ihtiyaçların giderilmesinde fiziksel güç kaybıyla birlikte ekonomik sorunlarla karşı karşıya kalmaları, 2. Bireylerin kente göç ederek orada yaşlanmaları ve yalnızlaşmaları, işverenler tarafından talep edilmeyen işgücü sınıfına girmesiyle ciddi ekonomik, sosyal ve psikolojik sorunlar yaşamalarıdır.

Modernleşmeyle birlikte değişim ve dönüşüme uğrayan önemli kurumlardan biri de aile kurumudur. Geleneksel geniş ailenin yerini çekirdek aileye bırakması, aile kavramının anlam ve işlevinde de değişiklikler meydana getirmiştir. Geleneksel geniş ailede yaşlı birey saygı duyulması, sözü dinlenmesi gereken itibarlı kişiliktir. Ancak çekirdek aileye evrilmeyle birlikte yaşlı birey aile dışında bırakılmaya başlanmıştır ve bu da yaşlı bireyin aile içindeki önemini ve itibarını sarsan bir durum olmuştur. Tüm bunlarla birlikte teknolojinin gelişmesi, üretim sürecinde daha az insan gücünün kullanılması, eğitime verilen önemin artması, sağlıklı beslenme, sağlık hizmetlerinin hızı ve kalitesinin artmasıyla birlikte insan ömrünün uzaması gibi değişme ve gelişmelerle birlikte, yaşlı nüfus sürekli olarak artmaktadır. Artan yaşlı nüfusunun talep ve beklentilerinin yeterince karşılanamaması ise; yoksulluk, dışlanma ve yalnızlık sorunlarını beraberinde getirmektedir.

Türkiye İstatistik Kurumu (TÜIK) nüfus projeksiyonları incelendiğinde Muğla ilinin yaşam süresinin ülke ortalamasına göre uzun olduğu görülmektedir. Muğla' da yaşayan bireylerin az çocuk dünyaya getirmeleri, eğitime önem vermeleri, sağlıklı beslenmeleri yaşam sürelerinin uzun olmasını açıklar niteliktedir. Bu olumlu durum, bazı olumsuzlukları da beraberinde getirmektedir. Bireylerin az çocuk dünyaya getirmesi ve bu çocukların eğitimlerine şehir dışında devam etmeleri, ailelerinin çocuklarına destek olmak için bütün imkânlarını seferber etmeleri bireyleri hem maddi hem de manevi açıdan olumsuz etkileyebilmektedir. Eğitime önem verilmesinde Muğla'nın iş bulma imkanlarının sınırlı olması, dağlık coğrafyaya ve dağınık bir yerleşime sahip olması da etkilidir.

Yaşlı bireylerin yaşadıkları en önemli sorunlar arasında yalnızlık, bakım ihtiyacı ve yoksulluk yer almaktadır. Yaşlı bireylerin yalnızlığı ve yaşlılık ile birlikte gelen psikolojik, biyolojik, fizyolojik sorunlar aynı zamanda yoksullaşmalarına da neden olmaktadır. Bunun nedeni olarak yaşlı bireyin maddi imkânlara sahip olsa dahi bu imkânları kullanabilecek fiziksel yetiye sahip olamamaları gösterilebilir. Çünkü yaşı bireylerin bakım sigortası olarak 
gördükleri çocukları kendi çekirdek ailelerini kurdukları için anne babalarından uzaklaşmaktadırlar. Bireylerin üretkenlik sürecinde çocukları adına maddi ve manevi olarak fazlaca çabalamaları nedeniyle durgunluk döneminde üretimden çekilmenin vermiş olduğu bir eksiklikle bireyler, "işe yaramama, kendine ve başkasına yetememe duygusu"na kapılmaya başlayabilmektedirler. Bu etkenler Muğla'da yaşlılığın sosyal bir sorun halini almasının nedenini açıklar niteliktedir.

\section{Yaşlılık}

Yaşlılık, bireyin yaşadığ evredir. Beauvoir, yaşlılığın biyolojik bir olay olduğunu ve psikolojik sonuçlar doğurduğunu dile getirmektedir. Yaşlılık, bireyin zamanla olan ilişkisini değişikliğe uğratır. Başka bir deyişle Beauvoir'a göre yaşlılık statik bir olgu değildir; aksine bir sürecin sonuçlanması ve devamidır (Beauvoir, 1970, akt.: Uysal, 1993: 20, 23).

Popüler kültürün yaşlı tanımı yaşlı bireyleri açıkça sosyal dışlanmaya maruz bırakan bir tanımdır: "yaşlı insanlar bunak, özgünlükten yoksun, sessiz, tüketen, tutucu ve değişime kapalı" olarak karakterize edilmektedir. Bu tanımın aksi bir durum olduğu aslında aşikârdır. Yaşlı bireylere imkân verildiğinde ne kadar aktif ve üretken oldukları gözlemlenmektedir (Kornblum ve Julian, 2011, akt.: Zastrow, 2013: 641).

Fizyolojik bir süreç olarak ele alınan yaşl1lık biyolojik, psikolojik, ekonomik ve sosyal değişkenlerden oldukça fazla etkilenen yaşam evresidir. Uysal, yaşlılığı üç farklı boyutta ele alarak şu şekilde açıklamıştır: "1. Biyolojik yaşlılık: Bireyin gelişim sürecinde vücut organları ve sistemlerindeki işlevsel ve yapısal değişimdir. 2. Psikolojik yaşlılık: Bireyin gelişim sürecinde yaşa bağlı olarak deneyimlerinin artmasıyla oluşan davranış değişiklikleri ve toplumun diğer bireyleriyle uyum içerisinde olabilme kapasitesidir. 3. Sosyolojik yaşl1lık: Bireyin yaşamı boyunca toplumsal statü ve rollerinin değişmesine paralel olarak beklentileri ve normlarının değişmesi ile ilgilidir” (Uysal, 1993: 1).

Yaşlılığı ve yaşlanma sürecini anlayabilmek için yukarıdaki tanımlamalar dışında dikkatle ele alınması gereken bir diğer tanım "yaşlanan nüfus" tanımıdır. Yaşlanan nüfus, yaşam beklentisindeki artış ve toplumun yaşlanması olarak açıklanabilir. ADNKS, 2016 sonuçlarına göre, Türkiye nüfusunun \% 8,3'ünü 65 yaş ve üstü bireyler oluşturmaktadır. Nüfus projeksiyonlarına göre 65 yaş ve üstü bireylerin yoğunluğunu gösteren üç senaryo bulunmaktadır. İlk senaryoda 2013 yılında 7,7 olan yaşlı nüfus oranının 2023 yılında 10,2, 2050 y1lında 20,8, 2075 y1lında ise 27,7 olacağ tahmin edilmektedir. İkinci senaryoda 2023 yılında 10,1, 2050 yılında 18,7, 2075 yılında ise 20,7 olması beklenmektedir. Üçüncü senaryoda ise 2023 y1lında 10,1, 2050 yılında 17,6 ve 2075 y1lında 17,5 olacağ tahmin edilmektedir. TÜIK 16 Mart 2017 tarihinde yayınladığı haber bültenine göre, ortalama yaşam süresinin 78 (Muğla'da 80,1) yıl olduğu göz önünde bulundurulduğunda, 2050 yılında ortalama yaşam süresinin Türkiye'de 80 yıl civarında olacağı düşünülmektedir (TÜIKK, 2016).

Araştırma evrenini oluşturan Muğla'ya bakıldığında, 923.773 olan genel nüfus içindeki yaşlı nüfus sayısı 105.660'tır. Muğla için yaşl1lık önemli bir sorun olarak nitelendirilebilmekte ve gelecekte de bu sorunun artarak devam edeceği düşünülmektedir. TÜİK verilerine göre; Muğla nüfusunun 2023 yılında 995.128 kişi, 2050 yılında ise 1.272 .273 kişi olacağ tahmin edilmektedir. Yine TÜIK verilerinin nüfus projeksiyonlarına göre; Muğla yaşlı nüfusunun 2023 yılında 12,9; 2050 yılında ise 21,4 olacağı tahmin edilmektedir (TÜíK, 2016-1). 


\section{Yoksulluk ve Yaşlı Bireylere Etkileri}

Yoksulluk, özel mülkiyetin ve insanlar arası üretimden kaynaklanan farklılaşmanın başladığı günden bu yana, bir şekilde var olan bir olgudur. Kitle iletişim araçlarının gelişmesiyle daha da artan kürsellleşmeyle birlikte, gelişmiş toplumlarda ekonomik büyümenin yavaşlaması, toplumların pazar tarafindan yönlendirilmesi gibi nedenlere bağlı olarak artan işsizlik, yoksulluğu daha bir görünür hale getirmiştir. Yoksulluk, 19. yüzy1ldan bu yana birey veya sistem ile bağlantı kurularak açıklanmaya çalışılmıştır. Bireysel teorilere göre yoksulluk bireyle ilintilidir. Dolayısıyla bireyin yoksulluk kaynağının toplum ya da içinde yaşadığı sosyal grup olmadığına dikkat çekilmektedir. Bireysel teorilere göre yoksul olan kişi eğer yeterince çalışmıyor ve gelirini artırmak istemiyorsa ya da bunun için herhangi bir çaba sarf etmiyorsa yoksulluğu kabullenmek konumundadır. Yoksulluğu sistemle bağlantılı olarak açılayan sosyal bilimciler, yoksul bireyin bir kurban olarak nitelendirilmesi gerektiğini ve toplumda tabakalaşma olduğu sürece, bir grubun diğerine göre daha alt tabakadan ya da yoksul konumda olacağını iddia etmektedirler (Oktik, 2008: 21-27).

Yoksulluk en basit şekliyle ele alındığında, bireylerin insanca yaşaması için temel ihtiyaçlarını kendi imkanlarıyla karşılayamaması tanımı ile karşılaşılmaktadır. Birey ihtiyaçları yalnızca temel ihtiyaçlar ile sınırlı kalmadığından bu tanımın oldukça yetersiz kaldığı düşünülmektedir (Özmete, Hablemitoğlu ve Yıldırım, 2012: 4-5). Yoksulluk, bireyi yoksunluklarla yüz yüze bırakmaktadır. Dolayısıyla yüzeysel kalan bu tanıma karşın çeşitli yaklaşımlar ortaya çıkmıştır:

\subsection{Mutlak Yoksulluk}

Birey veya hane halkının fizyolojik ihtiyaçlarını karşılayabilmesi bağlamında yaşamını sürdürebilecek asgari refah düzeyini yakalayamaması durumudur. Mutlak yoksulluk biçiminde bireyin asgari ihtiyaçlarını karşılayıp karşılayamaması kıstas olarak alınmakta; karşılayamadığı durumlarda birey yoksul olarak nitelendirilmektedir. (Tokol ve Alper, 2011: 122). Mutlak yoksulluk, günümüzde birçok azgelişmiş ülkede minimum kalori ihtiyacina karşılık gelen gıda ihtiyacının yanı sıra eğitim, sağlık, barınma gibi temel gereksinim harcamaları da dikkate alınarak hesaplanmaktadır (Şenses, 2006: 64). Bireyin yaşamını insani koşullarda sürdürebilmesi için ihtiyacı olan gıdayı karşılayamaması, kendini koruyabileceği bir barınağa sahip olmaması, asgari sağlık hizmetlerinden yararlanamaması ve temiz içme suyuna erişememesi, mutlak yoksulluk olarak tanımlanmaktadır (Kabasakal, 1998: 32).

\subsubsection{Gıda Yaklaşımı}

Yoksulluğun belirlenmesinde sadece yeterli miktarda gıda maddesinden oluşan gıda sepetinin maliyeti veya bir insan tarafindan alınması gereken asgari kalori miktarının gerektirdiği tüketim harcamaları esas alınmaktadır. Bu yaklaşıma gore, gerekli gıda ihtiyacını karşılayamayan birey yoksul olarak kabul edilmektedir (Tokol ve Alper, 2011: 122, 123). Yaşlı bireyler açısından bakıldığında en önemli sorunlardan birinin sağlıklı ve yeterli gıdaya erişebilme, dengeli ve sağlıklı beslenme sorunu olduğu gözden kaçmamalıdır. 


\subsubsection{Temel İhtiyaçlar Yaklaşımı}

$\mathrm{Bu}$ yaklaşımda, asgari gıda ihtiyacının yanında; giyinme, barınma, ısınma gibi diğer temel ihtiyaçların karşılanamaması durumunda birey yoksul kabul edilmektedir (Tokol ve Alper, 2011: 124). Tıpkı gıda ihtiyaçlarının giderilmesinde olduğu gibi yaşlı bireylerin temel ihtiyaçlarının karşılanmasında da sorunlar bulunmaktadır.

\subsection{Göreli (Nispi) Yoksulluk}

Göreli yoksulluk, bireyin yaşam düzeyini, kendisinden daha yüksek yaşam düzeyleri ile kıyaslaması sonucu ortaya çıkan bir durumu ifade etmektedir. Göreli yoksulluk, bireyin toplumsal bir varlık olmasından yola çıkarak, yoksulluğu bireyler arası eşitsizlik olgusu olarak ele almaktadır. Bu noktada bireyin yoksulluk nedeniyle toplumsal alanda dişlanma yaşadığı söylenebilir. Çünkü sosyal refahının olmayışı bireyin eğlence gibi ihtiyaçlarından mahrum kalmasına neden olmaktadır. Birey, yoksul olan ve olmayan arasında var olan çizgi nedeniyle o refaha ulaşamamaktadır (Şenses, 2006: 64-65). Yaşlılık, kendi başına bir toplumsal dışlanma sebebi sayılırken, üstüne bir de yoksulluk ve bağlı başka sorunlar eklendiğinde yaşlı bireylerin yaşadığı sorunlar daha fazla artmaktadır.

\subsection{Objektif Yoksulluk}

Objektif yoksulluk yaklaşımı uzmanlar tarafından önceden belirlenen değerleri içermektedir. $\mathrm{Bu}$ değerler içerisinde yoksulluğun temelinde ne olduğu ve bireylerin yoksulluktan kurtulabilmeleri için nelerin gerektiği soruları yer almaktadır (Aktan ve Vural, 2002: 6). Nesnel yoksulluk olarak da değerlendirilen objektif yoksulluk yaklaşımında, kalori miktarı, gelir ve tüketim harcamaları gibi somut ölçekler kullanılmaktadır. Bununla birlikte söz konusu ihtiyaçlar, uzmanlar tarafından belirlenen mal ve hizmetlerin satın alınabilmesi için gerekli olan en düşük maliyeti yansıtan ihtiyaç düzeyi olarak belirlenmektedir (Kaya, 2011: $34)$.

\subsection{Subjektif (Öznel) Yoksulluk}

Subjektif yaklaşımda asgari temel ihtiyaçlarının karşılanıp karşılanmadığı konusunda kişilerin kendi algılayış biçimleri ön plandadır. Yoksulluk bireyin ihtiyaçlarının karşılanmasına göre değil de toplumda bulunan konuma göre yorumlanır hale gelmiş durumdadır. Öznel yaklaşıma göre toplumun kabul edebileceği bir asgari hayatın belirlenmesi yerine, fertlerin görüşlerinin dikkate alınması gerekmektedir (Tokol ve Alper, 2011: 125).

SHÇEK Ayni ve Nakdi Yardım Yönetmeliği'nin 4. Maddesinde ise yoksulluk; “kendisini, eşini ve bakmakla yükümlü olduğu çocuklarını, anne ve babasını mevcut yaşam koşullarına göre asgari düzeyde geçindirmeye yetecek geliri, malı ya da kazancı bulunmama durumu" olarak belirlenmiştir (Özmete, Hablemitoğlu ve Yıldırım, 2012: 4-5). Bu tanım SHÇEK Ayni ve Nakdi Yardım Yönetmeliği'nde önceden yer alan tanımdır. Ancak mevcut yönetmelikte yoksulluk kavramına yer verilmemiş yalnızca yoksunluktan söz edilmiştir. Bununla birlikte her iki yönetmelikte de yoksulluk ve yoksunluk kavramlarının herhangi bir şekilde tanımlaması yapılmadan kullanıldığı görülmektedir (http://www.resmigazete.gov.tr, https://ankara.aile.gov.tr).

Yoksulluk, genel olarak yeterli kaynak ve gelir sahibi olamama durumu olarak tanımlanabilir. Bunun yanı sıra insan yaşantısının onurlu bir şekilde sürdürülebilmesi için 
gerekli olan gıda, su, giyecek, barınma ve sağlık hizmetlerinden yararlanma gibi temel insani gereksinimlerden yoksun olmasıdır. Yoksulluk insanın temel ihtiyaçlarının bile karşılanamadığı dönemlerin yaşandığı yaşam kalitesinin düşüklüğüdür de denilebilir (Oktik, 2008: 21-22).

İnsanlar, eğer gelir ve kaynaklarındaki yetersizliklerden dolayı içinde bulundukları toplumca kabul edilebilir olarak değerlendirilen bir yaşam standardı seviyesini tutturamıorlarsa yoksulluk içerisindedirler. Böyle bir durumda, yoksul kesim bir dizi sorunu birlikte yaşamaya mahkumdur: İşsizlik, düşük gelir, kötü yerleşim koşulları, sağlık hizmetlerinden yeterli düzeyde yararlanamama ve kültür, spor, dinlenme ve eğitim olanaklarına yaşam boyu ulaşmada engeller. İktisadi, toplumsal ve kültürel hayatta diğer insanların doğal hayat akışı içerisinde yapa geldikleri etkinliklere hakkıyla katılamazlar ve temel haklarına ulaşımda zorluklar yaşayabilirler (Adaman ve Keyder, 2006: 5).

\section{Yaşlı Yoksulluğu ve Yarattı̆ğ Sorunlar}

Günümüz modern toplumlarında yukarıda çoğundan bahsedilen sebeplerle insan ömrünün uzamasıyla birlikte bağımlı bir nüfus grubunu oluşturan yaşlılara ilişkin sosyal sorunların tartışılması gündeme gelmiştir. Yaşlanmayla birlikte bireyler üretici konumundan tüketici konumuna geçmekte ve maddi problemler yaşamaktadırlar. Dolayısıyla yaşlı bireylerin gelir kaynaklarında ortaya çıkan değişiklikler yaşam biçimlerinin de değişmesine neden olabilmektedir. Özellikle emeklilikle birlikte gelirin azalması, sahip olunan sosyal statü kaybı, bireylerin toplumsal alanda iletişim ve etkileşimlerini de etkilemektedir. Bunun yanı sıra zihinsel ve fiziksel gerileme, üretici rolünün önemli oranda azalması, sosyal konumda değişme, sağlığın kaybı gibi özgün sorunların ve bu dönemde ortaya çıkan kayıpların birbiri ile kesişmesi yoksulluğa neden olmaktadır (Özmete, Hablemitoğlu ve Yıldırım, 2012: 8-9).

Yaşlanmanın getirdiği fiziksel, biyolojik, psikolojik değişmelerin yanı sıra sosyal ve ekonomik ihtiyaçlar da yaşın ilerlemesiyle birlikte değişiklik göstermektedir. $\mathrm{Bu}$ değişikliklerden birisi de emeklilik dönemine geçiştir. Bireylerin yaşl1lık sürecinde üretim "kalitelerinin" düşmesi sanayileşmiş toplumlarda yaş kavramının ayırt edici bir etmen olarak rol oynamasına neden olmaktadır. Emeklilik sonrası gelir düzeyindeki düşüş, makineleşmenin ve hızlı nüfus artışının neden olduğu istihdam sorunu, yaşlılığın getirdiği sağlık problemlerinden dolayı çalışma yaşamından uzaklaşma, hayat pahalılı̆̆ı, paranın alım gücünün azalması gibi nedenlerle yaşlılık döneminde ekonomik sorunlar ve yoksullukla karşılaşılmaktadır. Yaşlı yoksulluğunu etkileyen en önemli faktörlerden biri de işgücü piyasasında var olan eşitsizliklerdir. İşveren kuruluşlar ya da kişiler yaşlı bireylerle çalışmayı çoğunlukla tercih etmemektedirler. Yaşlılık döneminde bireyin çalışma hayatına katılamaması ve yaşlı bireylere iş imkânının verilmemesi yoksulluğun nedeni olmaktadır. Özellikle yaşlı kadınların işgücü piyasasında görülme oranları oldukça düşüktür. Genellikle tarımsal alanlarda "ücretsiz aile işçisi”" olarak kalmaktadırlar. Göçle birlikte kente yerleşen yaşlı kadın veya kentte sosyal güvencesiz yaşlanan kadın ise kentte aranılan sektörün niteliklerinden yoksun olduğu için genellikle evine kapanmakta ve çalışma hayatında yer alamamakta, en fazla torun bakıcısı işlevi görmektedir. Dolayısıyla, kadınlar kentlerde gündelik temizlik işleri, çocuk bakıcılığ 1 gibi sosyal güvencesi olmayan işlerde çalışmak zorunda kalmaktadırlar. Sosyal güvencesiz çalışmak ise yaşl1lı̆̆ın sağlık sorunlarıyla, yoksullukla geçmesine neden olmaktadır (Karadeniz ve Öztepe, 2013: 92).

Yaşlı bireylerin günümüzde en önemli sorunları arasında parasal güvence yokluğu, bakım ihtiyacı ve dolayısıyla yoksulluk yer almaktadır. Aile olgusunun kökeninde gerçekleşen değişimle birlikte yaşlıların bakım sigortası olarak görülen genç kuşaklar kendi çekirdek 
ailelerini kurup, ana-baba ocağından uzaklaşmaktadırlar. Böylece yaşlılık, önemli derecede ekonomik, psiko-sosyal sorunların yaşandığı bir dönem haline gelmektedir. Türkiye'de ekonomik ve siyasi değişmeler sosyo-kültürel değişmeleri de beraberinde getirmiştir. Ailenin işlevinin ve yaşam tarzının değişmesiyle birlikte yaşlının aile içindeki yeri, önemi, gücü ve otoritesi önemli ölçüde azalmıştır. Özellikle sosyal güvenlik kapsamı dışında yer alan yoksun, yoksul bireylere bakmak, onların ihtiyaçlarını gidermek evlatlar için de bir külfet olmaya başlamıştır. Dolayısıyla toplum, yoksul, yoksun, kimsesiz, düşkün yaşlılara devletin bakmasını istemiştir. Bu durum ve davranışlar yaşamın son evresi olarak görülen yaşlılığın daha da sorunlu bir süreç olarak yaşanmasına neden olmaktadır. Yaşlilıkla birlikte gelen fiziksel ve zihinsel yeti kaybı, kendine yetememe duygusu, üretkenlikten çekilme gibi durumlar yaşlı bireylerin oldukça sorunlu bir süreç yaşamalarına neden olurken buna bakım ihtiyacı ve yoksulluk gibi önemli problemlerin eklenmesi de yaşlılık sürecini yaşanması güç bir süreç haline getirmektedir (Danış, 2009: 1-4).

Dünya'da ülkelere göre değişen yaşam süresi, bölgelere göre de değişiklik göstermektedir. Özellikle Muğla ilinde ortalama yaşam süresi ülke ortalamasına göre uzundur. Bunun sebeplerine bakıldığında sağlıklı yaşam ve az çocuk dünyaya getirme başat etmenler arasında yer almaktadır. Ancak yaşam süresinin uzun olması yoksulluğa tam olarak çözüm üretememiştir. Çocuk ortalamasının düşük olduğu Muğla ilinde yaşayan bireyler, çoğunlukla ekonomik gelir kaynaklarının ve iş imkanlarının sınırlı olmasından dolayı eğitime önem vermekte ve çocuklarının geleceklerini garantiye alma isteğiyle çocuklarını her şartta okula gönderip meslek sahibi yapmaya çalışmaktadırlar. Yetişkin birey haline gelen çocuklar çekirdek aile kurarak ebeveynlerin yanından, bazen de bölgeden uzaklaşmaktadırlar. $\mathrm{Bu}$ durum, geride kalan yaşlı ebeveynlerin hem çocuk özlemi çekmesine hem de yoksunluk ve yoksulluğa sebep olabilmektedir. Yoksulluk ve yoksunluk bireylerin sosyal dişlanmaya maruz kalmalarına da sebep olmaktadır. Sosyal dışlanmaya maruz kalan bireyler yoksulluk ve yoksunluklarını daha fazla hissetmektedirler. Bu nedenle, sosyal dışlanma kavramı da yaşlı yoksulluğuyla birlikte üzerinde durulması gereken önemli bir kavramdır.

\subsection{Sosyal Dışlanma}

Sosyal dışlanma kavramı genellikle yoksulluk ve yoksunluk kavramları ile birlikte anılmaktadır. Ancak yoksulluk ve yoksunluk kavramları bireyden bireye, ülkeden ülkeye ve toplumdan topluma farklı1ıklar gösterdiği için üzerinde hemfikir olunan bir sosyal dişlanma tanımı yapmak zorlaşmaktadır. Genel bir tanım ile sosyal dışlanma, toplum ile birey arasında bütünleşme sağlayabilecek birtakım ekonomik ve sosyal haklardan yoksun olmak, mahrum bırakılmaktır (Öztepe, ve Ulutaş, 2013: 309). Marshall'a göre sosyal dışlanma ise, bireylerin ya da hane halklarının kaynaklardan ve toplumsal bütünleşmeden yoksun birakılması süreci olarak ifade edilmektedir (Marshall, 1999: 150).

Küreselleşme sürecine paralel olarak ortaya çıkan sosyal dışlanma kavramı, günümüzde üzerinde hassasiyetle durulması ve çözüm bulunması gereken sorunların başında yer almaktadır. Yoksulluğun artması ve toplumsal alanda yaygınlık göstermesi sosyal dışlanma sorununun önemini bir kez daha ortaya koyar niteliktedir (Öztepe ve Ulutaş, 2013: 309). Sosyal dışlanma kavramı yoksulluk kavramı üzerine inşa edilmiş olsa da tarihsel süreçte tanımlama konusunda tartışmaların yoğun olduğu görülmektedir. Bu tartışmalar, yoksulluk ve sosyal dışlanma kavramlarının aynı olduğu, modernleşmeyle birlikte çağa ayak uydurmak için yoksulluk kavramının isim değiştirdiği, aralarında benzerlik ve farklılıkların bulunduğu konular üzerinde yoğunlaşmaktadır. Ancak Levitas'a (2000) göre, sosyal dışlanmanın anlamlarından biri olan bölüşüm yaklaşımı, sosyal dışlanmayı yoksulluğun bir sonucu olarak 
görmektedir (Akt.: Şahin, 2009: 82). Yoksulluk sadece maddi olanaklardan yoksunluk anlamında bir kavram olarak görülmemektedir. Çünkü bireylerin yaşadığ 1 maddi imkânsızlıklar, sosyal, kültürel ve toplumsal imkânsızlıkları da beraberinde getirmektedir. Sosyal dişlanma da yine bireylerin sosyal, kültürel, ekonomik, politik ve sosyal destek alanlarında yaşadığı yetersizliği tanımlamaktadır (Şahin, 2009: 39).

Özetle; bireylerin biyopsikososyal açıdan sağlıklı olmalarının temelinde yoksulluğun önemli bir yere sahip olduğu söylenebilir. Maddi imkânlara sahip olan yaşılı bireyler yalnızlıklarının etkisini azaltacak sosyal etkinliklere katılma, bakıcı veya yardımc1 tutma, yakınlarının kendisine daha yakın olabileceği koşulları sağlama gibi olanaklara da sahiptirler. Bunun yanı sıra sağlık, eğitim, güvenlik ve ulaşım gibi alanlarda yoksul bir bireye nazaran daha az sorunlarla karşılaşacaklardır. Yaşlandıkça zihinsel ve fiziksel yeti kaybı yaşayan bireylerin yaş sebebi ile sosyal dışlanmaya maruz kalmaları yaşlı bireyleri oldukça etkilerken, yoksulluk sebebiyle toplumdan dışlanmaları yaşamlarını daha da zor hale getirmektedir. Yaşam koşulları daha fazla zorlaşmış olan yaşlı bireyler toplumsal alandan hem dışlanmakta hem de ayrımcılığa uğramaktadırlar. Bu iki negatif durum yaşlı bireylerin yalnızlaşmasına ve yaşam kalitelerinin düşmesine sebep olmaktadır.

\subsection{Ayrimcilık}

Bireylerin, devlet ve kuruluşlarca eşitlik ilkesine aykırı olarak, haklarından yoksun bırakılması veya eşit olarak faydalandırılmamasıdır. Doğrudan ve dolaylı olarak iki türü vardır;

Doğrudan Ayrımcılık; din, etnik köken, cinsel yönelim, engellilik vb. olmak üzere bu gibi nedenlerle bir kişi veya grubun diğer kişi veya grupların faydalandığı hak ve özgürlüklerden ya hiç faydalanamaması ya da yeteri kadar faydalanamaması anlamına gelmektedir. (Gül ve Karan, 2011). Doğrudan ayrımcılı̆̆ın tespit edilebilmesi kolay olmamaktadır. Öncelikle kişilerin uğradıkları ayrımcılıkla ilgili bilgi sahibi olmaları, bilinçli bir şekilde bunu dile getiriyor olmaları, bilgilendirildiklerinde haklarını aramak için bir arayış ve çaba içinde olmaları gerekmektedir. Dolaylı ayrımcılık ise; herkes için geçerli ve tarafsız olan fakat bazı kişiler ve gruplar üzerinde diğer gruplar ve kişilerden daha fazla negatif etkiler ortaya çıkaran yasal düzenlemeler veya uygulamalar olarak tanımlanabilmektedir (Gül ve Karan, 2011: 14,15).

İnsan Haklar1 Evrensel Bildirgesi (IHHEB)'nin 25. Madde ve 1. F1krası'na göre; “Her insanın, yiyecek, giyecek, konut, sağllk hizmetleri ve gerekli toplumsal hizmetler de içinde olmak üzere; kendisinin ve ailesinin sağlık ve refahını sağlayacak uygun bir yaşam düzeyine hakkı vardir. Isssizlik, hastalık, sakatlı, dulluk, ihtiyarlık ya da geçim olanaklarından iradesi dışında yoksun kaldı̆̆ diğer hallerde sosyal güvence hakkına sahiptir." İHEB, yoksulluğu insan hakları ihlali olarak değerlendirmektedir. Ancak hemen her toplumda yoksul bireylerin varlığı bilinmektedir ve bunun önüne geçilmesi noktasında hükümetlerin ve uluslararası kuruluşların samimiyeti sürekli olarak kuşkuyla karşılanmaktadır. Yaşlı yoksulluğu konusunda da geleneksel yapıdan, inanç sisteminden, ahlak olgusundan kaynaklanan sebeplerle sürekli bir kutsiyet atfedilen yaşl1lık, görmezden gelinmese bile gerekli önem verilmemektedir. Bu nedenle dünya üzerindeki yoksulların önemli bir kısmı yaşlılardan oluşmaktadır.

Ayrımcılıkla ilgili en büyük mücadelenin ekonomik anlamda verilen mücadele olduğu söylenebilir. Ayrımcılık yoksulluğa neden olurken, yoksulluğun da ayrımcıllı̆ın esas nedenlerinden biri olduğuna dikkat etmek gerekmektedir. Hem yaşlılık hem de yoksulluk 
olarak dezavantajlı grupta yer alan bireyler toplumsal alanda negatif ayrımcıllı̆a uğratılarak sosyal dışlanmaya maruz bırakılmaktadırlar. $\mathrm{Bu}$ nedenledir ki devletlerin yoksullukla mücadelelerini dezavantajlı gruplar üzerinden de değerlendirerek çözüm yolları aramaları, ayrımcılıkla mücadele için önem arzetmektedir (Tokol ve Alper, 2011: 245, 246).

\section{Bulgular}

Bu çalışma, 2015 yılından beri süren, süreç içinde eksiklikleri giderilerek son şekli verilmiş hem nicel, hem de nitel olarak sürdürülen ve MSKÜ BAP tarafindan desteklen araştırmanın bir parçasıdır. Araştırma sürecinde, iki farklı saha çalışmasında, Muğla'nın Fethiye, Köyceğiz, Ortaca ve Menteşe ilçeleri sınırında kalan mahallelerde toplamda 512 katılımcıya ulaşılmıştır. $\mathrm{Bu}$ kapsamda 2015-2016 yılları arasında yapılan "Göç, Kentleşme ve Kentlileşme Bağlamında Yaşl Yalnızlığı" konulu araştırma, Menteşe ilçesi sinırları içerisinde bulunan mahallelerde yapılmış olup 339 katılımcıya ulaşılmıştır. 2016-2017 yılları arasında yapılan "Yaş̧l Yoksulluğu'nun Yarattığ Sosyal ve Psikolojik Sorunlar" konulu çalışma ise Fethiye, Köyceğiz ve Ortaca ilçelerinde bulunan mahallelerde yapılmış ve 173 kişiye ulaşılmıştır. Yukarıda sözü edilen çalışma, "Yaş̧lı Yoksulluğu'nun Yarattığı Sosyal ve Psikolojik Sorunlar" konulu çalışmayı destekler nitelikte olduğu için bulgular içerisinde "Göç, Kentleşme ve Kentlileşme Bağlamında Yaşll Yalnızlığı” konulu araştırmanın sonuçlarına da yer verilmiştir. Özetle birbirine paralellik gösteren bu çalışmalar sayısal verilerle de birbirini desteklemektedir. Muğla ilinde yapılan "Göç, Kentleşme ve Kentlileşme Bağlamında Yaşlı Yalnızlığı” konulu çalışmanın bulguları özetle şu şekildedir:

Araştırma kapsamında Menteşe'nin mahallelerinde yaşayan 339 katılımcıya ulaşılımıştır. Bu katılımcıların 182'si kadın, 156'sı erkek bireylerden oluşmakla birlikte araştırmaya katılan 1 kişi cinsiyetini belirtmemiştir. Örneklemin yaş ortalamasının 75 olduğu tespit edilmiştir. Ayrıca katılımcıların gelir dağılımına bakıldığında ortalama gelirin 1089 TL olduğu görülmüştür. Eğitim durumuna bakıldığında ağırlıklı olarak $(\% 61,4)$ ilkokul mezunudurlar.

Araştırmaya katılan bireylerin \% 54,6's1 evli, \% 42,2'si bekâr, boşanmış, dul (eşi ölmüş) olduklarını belirtmişler, \% 3,2'si ise bu soruya herhangi bir cevap vermemişlerdir. Bekar, boşanmış, dul (eşi ölmüş) bireylerden \% 82,5'i evlenmek istemediğini, \% 6,3'ü evlenmek istediğini belirtmiştir. Evlenmek isteyen bireylerin \% 77,8'i yalnız olduğu \% 11,1'i de eski düzenini tekrar kurmak için evlenmek istediğini belirtmiştir. Araştırmanın geneline bakıldığı zaman ise; yaşlı bireylerin \%30,1'i kendini yalnız hissettiğini, \%56,3’ü yalnız hissetmediğini ve $\% 12,1$ 'i bazen yalnız hissettiğini belirtmişlerdir. Araştırma sonucunda edinilen bilgi doğrultusunda yalnız yaşayan bireylerin oranı $\% 28,6$ olarak belirlenmiştir.

"Yaşlı Yoksulluğu'nun Yarattığ Sosyal ve Psikolojik Sorunlar" konulu araştırmanın bulguları ise aşağıda tablolarla birlikte gösterildiği gibidir. 


Tablo 1. Yaş
\begin{tabular}{|l|c|c|}
\hline & Sıklık & Yüzde \\
\hline 65-74 yaş aralığı & 70 & 40,5 \\
\hline $\mathbf{7 5 - 8 4}$ yaş aralığı & 78 & 45,1 \\
\hline 85 yaş ve üzeri & 25 & 14,5 \\
\hline Toplam & 173 & 100,0 \\
\hline
\end{tabular}

Köyceğiz, Fethiye ve Ortaca ilçelerinde gerçekleştirilen çalışmaya katılan bireylerin yaş ortalaması 76'dır. TÜİK (2016) verileri Muğla'da ortalama yaşam süresinin uzun olduğunu göstermektedir. Araştırma sahasında görüşülen bireylerin ömürlerinin uzun olması TÜiK verilerini destekler niteliktedir.

Tablo 2. Cinsiyet

\begin{tabular}{|l|c|c|}
\hline & Sıklık & Yüzde \\
\hline Kadın & 93 & 53,8 \\
\hline Erkek & 80 & 46,2 \\
\hline Toplam & 173 & 100,0 \\
\hline
\end{tabular}

Araştırma sonucunda elde edilen verilere göre; örnekleme dahil olan kadınların sayısı erkeklere oranla daha fazladır. Genel olarak kadınların erkeklerden daha uzun yaşamasından ve yaşlı nüfus içinde sayılarının fazla olmasından dolayı bu duruma uygun şekilde örneklem alınmasına dikkat edilmiştir.

Tablo 3. Gelir Durumu

\begin{tabular}{|l|c|c|}
\hline & Sıklık & Yüzde \\
\hline Cevapsız & 8 & 4,6 \\
\hline 0-199 TL arası & 3 & 1,7 \\
\hline 200-399 TL arası & 14 & 8,1 \\
\hline 400-599 TL arası & 2 & 1,2 \\
\hline 600-799 TL arası & 6 & 3,5 \\
\hline 800-999 TL arası & 13 & 7,5 \\
\hline 1000-1508 TL arası & 90 & 52,0 \\
\hline 1509 TL ve üzeri & 37 & 21,4 \\
\hline Toplam & 173 & 100,0 \\
\hline
\end{tabular}

Türkiye İşçi Sendikaları Konfederasyonu (TÜRK-ISŞ)'nun 2017 Haziran ayı verilerine göre, dört kişilik bir ailenin sağlıklı, dengeli ve yeterli beslenebilmesi için yapması gereken aylık gıda harcaması tutarı (açlık sınırı) 1.508,35 TL'dir. Gıda harcaması ile birlikte giyim, konut (kira, elektrik, su, yakıt), ulaşım, eğitim, sağlık ve benzeri ihtiyaçlar için yapılması zorunlu harcamaların toplam tutarı ise (yoksulluk sınır) 4.913,19 TL'dir (TÜRK-İş, 2017). Toplamda 173 kişi ile yapılan çalışmaya katılan bireylerin aylık hane halkı gelir dağılımına bakıldığında ortalama gelirin 1383 TL olduğu görülmektedir. Aylık hane halkı geliri 1000- 
1999 TL aras1 olan bireylerin sayıs1 101, 2000-2999 TL aras1 geliri olan bireylerin sayıs1 14, 3000- 3999 TL arası geliri olan bireylerin sayıs1 8, 4000 TL ve üzeri geliri olan bireylerin sayıs1 4'tür. Bu tabloya göre görüşülen 173 birey arasında 136 birey $(\% 78,6)$ açlık sınırının altında yaşamaktadır. Yapılan çalışmada yoksulluk sınırı baz alındığında 173 birey arasında 170 bireyin $(\% 98,2)$ yoksulluk sınırının altında yaşadığı görülmektedir.

Tablo 4. Eğitim Durumu

\begin{tabular}{|l|c|c|}
\hline \multicolumn{1}{|c|}{} & Sıklık & Yüzde \\
\hline Okuryazar değil & 52 & 30,1 \\
\hline Okuryazar & 31 & 17,9 \\
\hline İlkokul mezunu & 74 & 42,8 \\
\hline Ortaokul mezunu & 8 & 4,6 \\
\hline Lise mezunu & 5 & 2,9 \\
\hline Lisans mezunu & 3 & 1,7 \\
\hline Toplam & 173 & 100,0 \\
\hline
\end{tabular}

Yaşlı bireylerin eğitim durumunun \% 42,8 oranında ilkokul düzeyinde oldukları görülmektedir. Bunun yanında okur-yazar olmayan bireylerin de yoğunlukta olduğu (\% $30,1)$ dikkat çekmektedir. Hiçbir okul bitirmemiş bireylerin oranı \% 48'dir. 65 yaş üstü bireylerin eğitim durumlarının düşük olması, Muğla'da kısıtlı iş imkânlarının yanında çocuklarının eğitimine önem vermeleri üzerinde oldukça etkili olmaktadır.

Tablo 5. Medeni Durum

\begin{tabular}{|l|c|c|}
\hline & Sıklık & Yüzde \\
\hline Bekâr & 6 & 3,5 \\
\hline Evli & 99 & 57,2 \\
\hline Boşanmış & 3 & 1,7 \\
\hline Dul (Eşi vefat etmiş) & 64 & 37,0 \\
\hline Diğer & 1 &, 6 \\
\hline Toplam & 173 & 100,0 \\
\hline
\end{tabular}

Örneklem içinde evlilerin \% 57'den fazla olduğu görülmektedir. İkinci sırada ise, eşi vefat etmiş bireyler yer almaktadır. Eş kaybı biyopsikososyal açıdan yaşlı bireyler üzerinde oldukça olumsuz etkiler bırakmaktadır. Görüşme esnasında yaşlı bireylere yöneltilen "Sizce yalnızlık nedir?" sorusuna eşlerini kaybeden bireylerin neredeyse tamamı eşlerinin ölümünden söz etmişlerdir. Herhangi bir yakını ile yaşamasına rağmen eş ölümünün bireyin kendisini yalnız hissetmesine neden olduğu gözlemlenmiştir. 
Tablo 6. Sosyal Güvence

\begin{tabular}{|l|c|c|}
\hline & Sıklık & Yüzde \\
\hline Sosyal güvencesi olmayan & 20 & 11,6 \\
\hline SSK & 76 & 43,9 \\
\hline Bağ-Kur (Esnaf) & 21 & 12,1 \\
\hline Bağ-Kur (Çiftçi) & 33 & 19,1 \\
\hline Emekli Sandığı & 12 & 6,9 \\
\hline Yeşil Kart & 10 & 5,8 \\
\hline Diğer & 1 &, 6 \\
\hline Toplam & 173 & 100,0 \\
\hline
\end{tabular}

Tablo 6'da sosyal güvencesi olan bireylerden çok herhangi bir güvencesi olmayan bireyler dikkat çekmektedir. Görüşülen 173 birey arasında 20 bireyin herhangi bir sosyal güvencesi bulunmamaktadır. Yaşlılıkla birlikte artan sağlık sorunları maddi sorunlarla birleştiğinde yaşam şartlarını oldukça zorlu bir hale getirmektedir. Bunun yanı sıra sosyal güvence olarak yeşil kart kullanan bireylerin yaşlılık maaşı aldıklarına dikkat edilmelidir. Yaşılılı maaşı, herhangi bir mal ve mülke sahip olmayan, muhtaç durumda olan ve aylık geliri 119,62 TL'nin altında olan yaşlı bireylere üç ayda bir ödenen maaştır (http://www.sgk.gen.tr). Ancak yaşlılı maaşı insanların ihtiyaçlarının yalnızca küçük bir kısmını karş1layabilmektedir.

Tablo 7. Cocuk Sayısı

\begin{tabular}{|l|c|c|}
\hline & Sıklık & Yüzde \\
\hline Çocuğu olmayan & 9 & 5,2 \\
\hline 1 çocuğum var & 8 & 4,6 \\
\hline 2 çocuğum var & 25 & 14,5 \\
\hline 3 çocuğum var & 45 & 26,0 \\
\hline 4 çocuğum var & 22 & 12,7 \\
\hline 4'ten fazla çocuğum var & 64 & 37,0 \\
\hline Toplam & 173 & 100,0 \\
\hline
\end{tabular}

Çalışma için, kırsal bölgelerden daha fazla örneklem alındığından dört ve üzeri çocuğu olanların fazla olduğu görülmektedir. Kırsal bölgelerde fazla çocuk dünyaya getirme bağ bahçe gibi işlerde çalışma açısından önemlidir. Bunun yanı sıra ebeveynler yaşlandıkları zaman kendilerine bakmaları için, bir anlamda bakım sigortası olarak gördükleri için, çocuk dünyaya getirmektedirler. Ancak yapılan görüşmelerde bunun pratikte pek de karşılığının olmadığı saptanmıştır. Örneğin bu konuyla ilgili olarak bir görüşmeci; “... dokuz çocuğum var, çoğu da yakınımda yaşlyor. Babalarını çok erken kaybettim. Hem eşime hem çocuklarıma baktım zamanında, başka köylere gidip çalıştım sırtımda çuvalla yürüyerek döndüm. Onları büyütürken çok eziyet çektim. Ben dokuzuna birden baktım ama şimdi bana biri bile bakmıyor. Gelinler biz niye baklyoruz diğerleri baksın diye oğullarımı kışkırtıyorlar. Herkes birbirine atıyor beni, kimse bakmiyor ..." (G8) demiştir.

Geleneksel toplumsal yapı ve aile yapısı içinde çocuklar ebeveynlerin yaşlılıklarında onlara bakacak, her türlü ihtiyaçlarını karşılayacak ve yalnızlığa düşmesini engelleyecek bir tür bakım ve sağlık sigortası olarak görülmektedir. Ancak dünyanın ve ülkemizin geçirdiği 
sosyo-ekonomik değişimler zorunlu olarak bu algının değişmesine ortam hazırlamıştır. Çünkü günümüz ekonomik koşullarında değişen üretim yöntemleri, kırdan kente yoğun göç, bireylerin kazançlarının düşüklügü̆, yaşanılan mekanların koşulları (daha küçük ve daha az odalı olması vb.), aile yapısının çekirdek aileye dönüşmesi ile özellikle çalışıp üret(e)meyen yaşlı bireylerin aile için yük olarak algılanmasında etkili olmuştur. Bu noktada gençliğinde maddi manevi bir çok sorun yaşayan bireyler yaşlandıklarında bunun karşılığını alabileceği düşüncesinin de yok olmasıyla psikososyal açıdan çöküntü yaşamaktadırlar.

Tablo 8. Birlikte Yașama Durumu

\begin{tabular}{|l|c|c|}
\hline & Sıklık & Yüzde \\
\hline Yalnız yaşıyorum & 44 & 25,4 \\
\hline Esimle yaşıyorum & 82 & 47,4 \\
\hline Annemle/Babamla yaşıyorum & 1 &, 6 \\
\hline Kızımla/Oğlumla yaşıyorum & 25 & 14,5 \\
\hline $\begin{array}{l}\text { Çocuklarımla ve Torunlarımla } \\
\text { yaşıyorum }\end{array}$ & 8 & 4,6 \\
\hline Eşim ve Çocuklarımla yaşı̀orum & 12 & 6,9 \\
\hline Diğer & 1 &, 6 \\
\hline Toplam & 173 & 100,0 \\
\hline
\end{tabular}

Yaşlı bireylerin yaşadığı önemli sorunlardan biri de yalnızlıktır. Tablo 8'de görüldüğü gibi 44 birey yalnız yaşamaktadır. Tarihe bakıldığında yaşlının değeri dönemlere göre değişmektedir. Örneğin avcılık toplayıcılık döneminde yaşlının değeri düşüktür ancak tarım döneminde, toprağı yaşlı elinde tuttuğu için yaşl1lığa verilen değer ve önem yüksektir. Sanayileşmeyle birlikte gelişen modern toplumun da yaşlılara daha az değer verdiği görülmektedir. Dolayısıyla sanayileşmeyle birlikte yaşlının rolünün ve statüsünün teknolojinin gelişimi ile ters orantılı olduğu söylenebilir. Çünkü kentleşme ailenin parçalanmasına; teknolojik gelişmeler ise yaşlların bilgi ve tecrübelerine verilen önemin azalmasına neden olmuştur (Oğuz, 2007). Bunun yanı sıra, genç nüfusun kentlere yönelmesi yaşlı bireylerin kırda kalmasına sebep olmuş ve yaşlı bireyler yalnızlık ile karşı karşıya kalmışlardır.

“Göç, Kentleşme ve Kentlileşme Bağlamında Yaşlı Yoksulluğu” konulu araştırmanın bulgularına göre ise, bireylerin yalnız ve birisiyle/birileriyle birlikte yaşama durumunun yalnızlık hissetme durumu üzerinde etkili olduğu görülmektedir. $\mathrm{Bu}$ noktada yalnız yaşamakta olan bireylerin \% 59,8'i kendisini yalnız hissettiğini dile getirmiştir. Bu da sosyopsikolojik yalnızlıktır. Buradan hareketle fiziksel olarak yalnız olmanın aynı zamanda sosyopsikolojik olarak yalnızlık hissetme durumunu etkileyen bir faktör olduğu söylenebilir.

Araştırmaya katılan 173 birey arasında $136(\% 78,6)$ birey açlık sınırının altında yaşamaktadır. Bu bilgi çerçevesinde Tablo 9 incelendiğinde çocuklarından hiçbir şekilde maddi destek almayan bireylerin çoğunlukta olduğu görülmektedir. Hatta bireylere bu soru yansıtıldığında oldukça şaşkın bir tepkiyle "Ben maddi destek almıyorum, olsa onlar benden isteyecek ...” (G6) yanıtını vererek kendilerinin çocuklarına destek olduğunu belirtmişlerdir. 
Tablo 9. Çocuklardan Maddi Destek Alma Durumu

\begin{tabular}{|l|c|c|}
\hline & Sıklık & Yüzde \\
\hline Çocuklarından hiç maddi destek almayan & 129 & 75,7 \\
\hline Zaman zaman alıyorum & 24 & 13,9 \\
\hline Genellikle alıyorum & 4 & 2,3 \\
\hline Tek geçim kaynağım çocuklarım & 7 & 4,0 \\
\hline Çocuğum yok & 9 & 4,0 \\
\hline Toplam & 173 & 100,0 \\
\hline
\end{tabular}

Tablo 10. Eğitim Durumu ile Yoksulluk Algısının Karşılaştırılması

\begin{tabular}{|c|c|c|c|c|c|c|c|}
\hline & 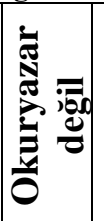 & 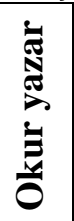 & 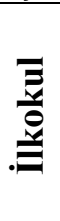 & 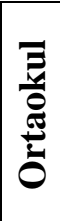 & $\stackrel{\mathscr{2}}{\leftrightarrows}$ & 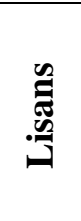 & 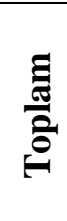 \\
\hline İstediğini alamamaktır & 0 & 0 & 1 & 0 & 1 & 5 & 7 \\
\hline Temel ihtiyaçların karşılanamamasıdır & 0 & 3 & 0 & 1 & 4 & 34 & 42 \\
\hline Maddi olarak muhtaç olmaktır & 1 & 1 & 0 & 0 & 1 & 10 & 13 \\
\hline Çalışmamak ve üretmemektir & 2 & 2 & 0 & 0 & 1 & 21 & 26 \\
\hline Yoksul hissetmediğim için bilmiyorum & 0 & 1 & 0 & 0 & 1 & 2 & 4 \\
\hline Toplumsal alanda dışlanmaktır & 0 & 0 & 1 & 1 & 1 & 8 & 11 \\
\hline $\begin{array}{l}\text { Ölüme yakın olmak yoksulluğu göz ardı } \\
\text { ettiriyor }\end{array}$ & 0 & 1 & 0 & 1 & 0 & 4 & 6 \\
\hline Parasızlık, yokluktur & 0 & 3 & 0 & 2 & 1 & 26 & 32 \\
\hline Çaresizlik, mutsuzluktur & 0 & 3 & 0 & 1 & 3 & 15 & 22 \\
\hline $\begin{array}{l}\text { Hiç gelirim yok ama kendimi yoksul } \\
\text { hissetmiyorum }\end{array}$ & 0 & 0 & 0 & 0 & 0 & 2 & 2 \\
\hline Toplam & 3 & 14 & 2 & 6 & 13 & 127 & 165 \\
\hline
\end{tabular}

Bireylerin eğitim durumları ile yaptıkları yoksulluk tanımları birlikte incelendiğinde, yapılan yoksulluk tanımlarının temel ihtiyaçların karşılanamaması üzerinde yoğunlaştığ görülmektedir. Ancak burada yoksulluğu tanımlarken "ölüme yakın olmak yoksulluğu göz ard1 ettirir" cümlesini kullanan bireylerin sayısına dikkat edilmesi gerekmektedir. Yaşamın son evresi olarak görülen yaşl11ıkta, yaşanan son günler olduğu düşüncesiyle varlıklı veya yoksul olma durumu önemsizleşmektedir. Bunun yanı sıra yoksulluğu "parasızlık ve yokluk" olarak tanımlayan bireylerin "yokluk" kavramının içini maddi imkânların tamamından yoksun olma ve kimsesiz olma durumu ile doldurduklarına dikkat çekmek gerekmektedir.

Yoksulluğu maddi-ekonomik anlam dışında yalnız olmayla bağdaştıran bir görüşmeci, "paran varsa eşin dostun akraban gelir gider, gençken para biriktirdim çocuklar ileride bana baktıklarında paylaştırayım diye ama onu hiç ettiler, şimdi de yüzüme bakan yok"(G8) yorumuyla açıklamıştır. Bu noktada toplumsal bir dışlanmaya maruz kaldığını hisseden bireyler maddi yetersizlik nedeniyle yalnızlaştıklarını belirtmişlerdir. Tablo 10 incelendiğinde eğitim durumu düşük olan bireylerin yoksulluk tanımlamalarının, "parasızlık ve yokluk, temel ihtiyaçların karşılanamaması ve çalışmamak, üretmemektir" yanıtları üzerinde yoğunlaştığı görülmektedir. 
Araştırmaya katılan bireylerin gelir durumları ile yoksulluk algıları (Tablo 11) birlikte incelendiğinde gelir durumu ile yoksulluk hissinin paralel olmadığı dikkat çekmektedir. Araştırmaya göre neredeyse hiç geliri olmayan bireyler kendilerini yoksul hissetmezlerken 1000 TL ve üzeri gelire sahip olan bireyler kendilerini daha fazla yoksul hissetmektedirler.

Tablo 11. Gelir Durumu ile Yoksulluk Algısının Karșılaştırılması

\begin{tabular}{|c|c|c|c|c|c|c|c|}
\hline Gelir/TL & $\frac{\partial}{\delta}$ & 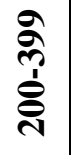 & $\begin{array}{l}\stackrel{8}{8} \\
\text { in } \\
8 \\
\stackrel{8}{+}\end{array}$ & 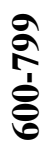 & 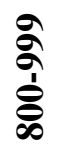 & $\stackrel{+}{\stackrel{\Xi}{8}}$ & $\frac{\Xi}{\tilde{\Xi}}$ \\
\hline İstediğini alamamaktır & 0 & 0 & 1 & 0 & 1 & 5 & 7 \\
\hline Temel ihtiyaçların karşılanamamasıdır & 0 & 3 & 0 & 1 & 4 & 34 & 42 \\
\hline Maddi olarak muhtaç olmaktır & 1 & 1 & 0 & 0 & 1 & 10 & 13 \\
\hline Çalışmamak ve üretmemektir & 2 & 2 & 0 & 0 & 1 & 21 & 26 \\
\hline Yoksul hissetmediğim için bilmiyorum & 0 & 1 & 0 & 0 & 1 & 2 & 4 \\
\hline Toplumsal alanda dişlanmaktır & 0 & 0 & 1 & 1 & 1 & 8 & 11 \\
\hline $\begin{array}{l}\text { Ölüme yakın olmak yoksulluğu göz ardı } \\
\text { ettiriyor }\end{array}$ & 0 & 1 & 0 & 1 & 0 & 4 & 6 \\
\hline Parasızlık, yokluktur & 0 & 3 & 0 & 2 & 1 & 26 & 32 \\
\hline Çaresizlik, mutsuzluktur & 0 & 3 & 0 & 1 & 3 & 15 & 22 \\
\hline $\begin{array}{l}\text { Hiç gelirim yok ama kendimi yoksul } \\
\text { hissetmiyorum }\end{array}$ & 0 & 0 & 0 & 0 & 0 & 2 & 2 \\
\hline Toplam & 3 & 14 & 2 & 6 & 13 & 127 & 165 \\
\hline
\end{tabular}

Bu noktada "yoksulluk kültürü" kavramına değinmek gerekmektedir. "Oscar Lewis tarafindan ortaya atılmış olan bu kavram, yoksulluğun içselleştirilmesi, bir kader olarak görülmesi neticesinde oluşan bir kültürel yapıyı anlatmak için kullanılmaktadır" (Akt.: Güllü, G., 2010). Hemen hiçbir geliri olmamasına ve insani şartların olabildiğince altında yaşamasına rağmen "param yok ama külliyetli borcum da yok" (G2) yanıtını veren görüşmeci kendini yoksul hissetmediğini dile getirmiştir.

"Göç, Kentleşme ve Kentlileşme Bağlamında Yaşlı Yoksulluğu” konulu araştırmanın bulgularında da, gelir düzeyi ile yalnız hissetme durumları arasındaki ilişki incelenmiştir. Geliri olmayan bireylerin \%75'i yalnız hissettiklerini belirtmişlerdir. Bunun yanında geliri 1 - $500 \mathrm{TL}$ arasında olan bireylerin oran $1 \% 43,5 ; 501$ - $1000 \mathrm{TL}$ arasinda olan bireylerin oran $\%$ 30,9; 1001 - $2000 \mathrm{TL}$ arasinda olan bireylerin oran $\%$ 24,3 ve $2001-3000 \mathrm{TL}$ arasinda olan bireylerin oranı ise \% 36,4 olarak belirlenmiştir. Bu oranlardan hareketle ekonomik durumun artış göstermesi ve yalnızlık hissetme durumu arasında ters bir ilişkinin olduğu söylenebilir.

Tablo 12'ye bakıldığında, araştırmaya katılan bireylerin yoksulluk tanımları ile çocuk sayısı birlikte incelendiğinde, dörtten fazla çocuk sahibi olan bireyler, yoksulluğu temel ihtiyaçların karşılanamaması şeklinde tanımlamışlardır. Bu noktada çok çocuklu ailelerde daha fazla geçim sıkıntısı yaşandığı genellemesine de gidilebilir. 
Tablo 12. Çocuk Sayısı ile Yoksulluk Algısının Karşılaştırılması

\begin{tabular}{|l|c|c|c|c|c|c|c|}
\hline & $\mathbf{0}$ & $\mathbf{1}$ & $\mathbf{2}$ & $\mathbf{3}$ & $\mathbf{4}$ & $\mathbf{5}+$ & Toplam \\
\hline İstediğini alamamaktır & 0 & 0 & 0 & 0 & 2 & 5 & 7 \\
\hline Temel ihtiyaçların karşılanamamasıdır & 2 & 2 & 6 & 11 & 7 & 16 & 44 \\
\hline Maddi olarak muhtaç olmaktır & 2 & 1 & 6 & 1 & 0 & 3 & 13 \\
\hline Çalışmamak ve üretmemektir & 1 & 3 & 3 & 7 & 4 & 9 & 27 \\
\hline Yoksul hissetmediğim için bilmiyorum & 0 & 1 & 1 & 0 & 0 & 2 & 4 \\
\hline Toplumsal alanda dışlanmaktır & 1 & 0 & 1 & 3 & 2 & 4 & 11 \\
\hline $\begin{array}{l}\text { Ölüme yakın olmak yoksulluğu göz ardı } \\
\text { ettirir }\end{array}$ & 2 & 0 & 1 & 4 & 0 & 1 & 8 \\
\hline Parasılık, yokluktur & 0 & 0 & 3 & 12 & 3 & 15 & 33 \\
\hline Çaresizlik, mutsuzluktur & 1 & 0 & 4 & 7 & 3 & 8 & 23 \\
\hline $\begin{array}{l}\text { Hiç gelirim yok ama kendimi yoksul } \\
\text { hissetmiyorum }\end{array}$ & 0 & 1 & 0 & 0 & 1 & 1 & 3 \\
\hline Toplam & 9 & 8 & 25 & 45 & 22 & 64 & 173 \\
\hline
\end{tabular}

Bir görüşmeci bu konuyla ilgili olarak; “.. şimdiki çocukların kendilerine hayırları yok, uzakta yaşlyorlar, gelmiyorlar, dul maaşım var iki ayda bir beni para çekmeye götürürken 50 lira almadan götürmezler. ..." (G8) demiştir. Yoksulluğu doğrudan toplumsal dışlanmayla ilişkilendirenlerin sayısı az olmakla birlikte net bir şekilde yaşlı bireyler tarafından bu şekilde yorumlanıyor olması önemlidir. Çünkü tek başlarına hem yaşlılık, hem de yoksulluk birer toplumsal dışlanma sebebidir.

Tablo 13. Yoksulluk Tanımı*Birlikte Yaşama Durumu

\begin{tabular}{|c|c|c|c|c|c|c|c|c|}
\hline & 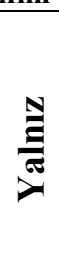 & 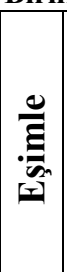 & 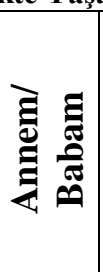 & 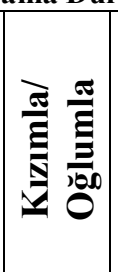 & 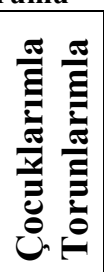 & 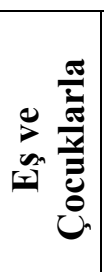 & סֶ: & 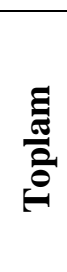 \\
\hline İstediğini alamamaktır & 0 & 5 & 0 & 0 & 0 & 2 & 0 & 7 \\
\hline $\begin{array}{l}\text { Temel ihtiyaçların } \\
\text { karşılanamamasıdır }\end{array}$ & 8 & 19 & 0 & 8 & 5 & 3 & 1 & 44 \\
\hline Maddi olarak muhtaç olmaktır & 5 & 4 & 0 & 3 & 0 & 1 & 0 & 13 \\
\hline Çalışmamak ve üretmemektir & 9 & 14 & 1 & 3 & 0 & 0 & 0 & 27 \\
\hline $\begin{array}{l}\text { Yoksul hissetmediğim için } \\
\text { bilmiyorum }\end{array}$ & 1 & 1 & 0 & 1 & 0 & 1 & 0 & 4 \\
\hline Toplumsal alanda dıșlanmaktır & 2 & 4 & 0 & 2 & 0 & 3 & 0 & 11 \\
\hline $\begin{array}{l}\text { Ölüme yakın olmak yoksulluğu göz } \\
\text { ardı ettirir }\end{array}$ & 4 & 3 & 0 & 0 & 1 & 0 & 0 & 8 \\
\hline Parasızlık, yokluktur & 8 & 20 & 0 & 3 & 1 & 1 & 0 & 33 \\
\hline Çaresizlik, mutsuzluktur & 6 & 12 & 0 & 4 & 0 & 1 & 0 & 23 \\
\hline $\begin{array}{l}\text { Hiç gelirim yok ama kendimi yoksul } \\
\text { hissetmiyorum }\end{array}$ & 1 & 0 & 0 & 1 & 1 & 0 & 0 & 3 \\
\hline Toplam & 44 & 82 & 1 & 25 & 8 & 12 & 1 & 173 \\
\hline
\end{tabular}


Örneklemi oluşturan bireylerin yaptıkları yoksulluk tanımları ile aynı evde birlikte yaşadıkları insanların olup olmaması arasındaki ilişki incelendiğinde eşiyle birlikte yaşayan bireylerin \% 19'u yoksulluğu "parasızlık, yokluk" olarak tanımladıkları görülmektedir. Tablo 13'de yalnız yaşayan yaşlı bireylerin yoksulluk algıları biyopsikososyal açıdan önemlidir. Çünkü yaşlılık sürecinde görülen en önemli sorunlardan biri de yalnızlıktır. Genç kuşakların kırsal alandan kente göçü sürekli olarak devam etmekte, yaşlılar ise genellikle kırsal alanda kalmakta ya da bırakılmaktadır. Günümüzde kırsal alandaki yaşlılık sorunlarının en önemlisi yaşlı bireylerin çocuklarından uzakta yaşıyor olmasıdır. Kentlerde sağlık hizmetleri gelişmiş ve teknoloji insan ömrünün uzamasına katkı sağlamıştır. Ancak kırsal alanda tüm olanaklardan ve çocuklarından uzak, parasal yoksunluk yaşayan yaşlılar kötü koşullarda yaşamlarını sürdürmektedirler. Söz konusu, gelişen sağlık hizmetlerinden ve teknolojiden yararlanamayan kırsal alanda yaşayan yaşlıların hayatları bu imkânsızlık nedeni ile oldukça zorlaşmaktadır. Bunun yanı sıra ülkemizde yaşlıların yaşam standartları gün geçtikçe düşmekte; yaşlı bireyler sağlik, beslenme, seyahat, serbest zaman değerlendirme, konut, bakım gibi sorunlarının yanı sıra yalnızlık ve yoksullukla da mücadele etmek zorunda kalmaktadır (Danış, Z., 2009).

"Göç, Kentleşme ve Kentlileşme Bağlamında Yaşlı Yalnızlı̆̆ ”" konulu araştırma sonucunda elde edilen veriler doğrultusunda, kentleşme ve kentlileşme ile birlikte meydana gelen toplumsal değişimden tüm bireyler gibi yaşlı bireyler de etkilenmekte ve dezavantajlı konumda yer almaktadırlar. Adı geçen araştırma kapsamında Muğla'daki yaşlı bireylerin \% 30'unun yalnızlık hissettiği sonucuna ulaşılmıştır. Bunun yanında yalnızlı hissetme durumunun fiziksel yalnızlıkla paralellik gösterdiği görülmektedir. Yaşamdan Geriye Çekilme Teorisi'ne göre birey ve toplum yalnızlaşma konusunda negatif etkileşim halindedir. Yaşlanan birey kendisini toplumdan geriye çekerken toplumdaki diğer bireyler de yaşlı bireylerin yalnızlaşmasına ve tolumdan soyutlanmasına izin vermektedirler. TÜIK 2013 yılı verileri incelendiği zaman Türkiye'de yaşlı nüfus oranı \% 7,7 iken; yaşlı bireylerin yalnız yaşama oran $1 \% 16$ olarak tespit edilmiştir. TÜİK 2015 verilerine göre Türkiye'de yaşlı nüfus oranı \% 8,2 iken; yaşlı bireylerin \% 17,6'sının yalnız yaşadığı belirtilmektedir. TÜIKK 2016 verilerine gore, Türkiye'de yaşlı nüfus oranı \%8,3 iken; tek kişilik hane halklarının \%36'sını yalnız yaşayan yaşlılar oluşturmaktadır. Bu noktada fiziksel yalnızlık ile yalnızlık hissetme durumunun paralelliğinden yola çıkılarak yaşlı yalnızlığının zamanla daha da önemsenmesi gereken bir konu halini alacağı söylenebilir.

“Yaşlı Yoksulluğu'nun Yarattı̆̆ Sosyal ve Psikolojik Sorunlar” konulu araştırma sonucunda elde edilen veriler doğrultusunda ise, yaşl1lık sürecinde yaşanan yoksulluk, bireyleri biyopsikososyal açıdan önemli derecede etkilemektedir. Muğla'nın Fethiye, Köyceğiz ve Ortaca ilçelerinde yapılan araştırma kapsamında bireylerin \% 98,2'sinin yoksulluk sınırının altında yaşadığı saptanmıştır. Yaşlı bireylerin yoksulluğunu etkileyen birden çok etkenden söz edilebilir. $\mathrm{Bu}$ etkenlerin başında yaşa bağlı olarak fiziksel ve zihinsel yeti kaybı gelmektedir. Fiziksel ve zihinsel yeti kaybı hem bireylerin çalışmalarını kısıtlamakta hem de toplumda işverenler tarafindan "vasıfsız" olarak nitelendirilebilmektedirler. Yaşlı yoksulluğu beraberinde yalnızlığı, ayrımcılığa ve sosyal dışlanmaya maruz bırakılmayı getirdiğinden, bireyler yaşl1l1k sürecinde sosyal ve psikolojik sorunlar yaşayabilmektedirler. 
Tablo 14. Derinlemesine Mülakatların Özeti

\begin{tabular}{|c|c|c|c|c|c|c|c|c|}
\hline Görüșmeci & G1 & G2 & G3 & G4 & G5 & G6 & G7 & G8 \\
\hline Yapılan Yer & Ortaca & Ortaca & Ortaca & Köyceğiz & Köyceğiz & Fethiye & Köyceğiz & Fethiye \\
\hline Cinsiyet & Kadın & Erkek & Kadın & Kadın & Erkek & Erkek & Kadın & Kadın \\
\hline Yaș & 70 & 70 & 77 & 68 & 70 & 86 & 69 & 81 \\
\hline Eğitim & Okuryazar & $\begin{array}{l}\text { İlkokul } \\
\text { mezunu }\end{array}$ & $\begin{array}{l}\text { İlkokul } \\
\text { mezunu }\end{array}$ & $\begin{array}{l}\text { Lise } \\
\text { Mezunu }\end{array}$ & $\begin{array}{l}\text { İlkokul } \\
\text { mezunu }\end{array}$ & $\begin{array}{l}\text { Okuryazar } \\
\text { değil }\end{array}$ & $\begin{array}{l}\text { Okuryazar } \\
\text { değil }\end{array}$ & $\begin{array}{l}\text { Okuryazar } \\
\text { değil }\end{array}$ \\
\hline Meslek & Ev Hanımı & Çiftçi & Ev Hanımı & Hemşire & Dalgıç & Çoban & Ev Hanımı & Ev Hanımı \\
\hline Gelir & 1350 & 1500 & 1100 & 1700 & 1000 & 600 & 1000 & 250 \\
\hline $\begin{array}{l}\text { Medeni } \\
\text { Durum }\end{array}$ & Dul & Evli & Dul & Evli & Boşanmış & Evli & Evli & Dul \\
\hline Ev & Kendisinin & Kendisinin & Kendisinin & Kendisinin & Kendisinin & Kendisinin & Kendisinin & Kendisinin \\
\hline $\begin{array}{l}\text { Çocuk } \\
\text { Sayısı } \\
\end{array}$ & 2 & 7 & Yok & 1 & 1 & 2 & 4 & 9 \\
\hline $\begin{array}{l}\text { Yoksulluk } \\
\text { Hissi }\end{array}$ & Yok & Var & Yok & Yok & Var & Var & Var & Var \\
\hline $\begin{array}{l}\text { Yalnızlık } \\
\text { Hissi }\end{array}$ & Var & Yok & Var & Yok & Var & Var & Var & Var \\
\hline $\begin{array}{l}\text { Kendine } \\
\text { Bakabilme }\end{array}$ & Bakabiliyor & Bakabiliyor & Bakabiliyor & Bakabiliyor & Bakabiliyor & Bakamıyor & Bakamıyor & Bakabiliyor \\
\hline $\begin{array}{l}\text { Birlikte } \\
\text { yaşama }\end{array}$ & Yalnız & Eşiyle & Yalnız & Eşiyle & Yalnız & $\begin{array}{l}\text { Eşiyle/ } \\
\text { Çocuğuyla }\end{array}$ & Eşiyle & Yalnız \\
\hline $\begin{array}{l}\text { Engel } \\
\text { Durumu }\end{array}$ & Görme & Yok & Yok & Yok & Yürüme & Görme & Yok & Yok \\
\hline
\end{tabular}

Sahaya çıkıldığında anket uygulanan bireylerden farklı olarak, her mahallede derinlemesine görüşmeler de yapılmıştır. Bu görüşmelerde anket sorularına paralel sorular yöneltilerek, gündelik yaşamlarında ekonominin yeri, yoksulluğun etkileri ve yalnızlık olgusu üzerinde durulmuştur. Görüşme yapılan bireyler, ankette de olduğu gibi yaş ve cinsiyet kriteri dışında tamamen tesadüfi olarak seçilmiştir. Buna göre, kırsal alanda yaşayanların kendilerini yoksul hissetmeleri kentte yaşayanlara göre daha düşüktür. Buradaki temel fark, kırsal alandaki yaşlıların, kente göre daha dar, herkesin birbirini tanıdığı alanlarda yaşamaları, yoksulluğun, insanların hala utandığı kötü bir durum olarak algılanması ve muhtaçlığın başkaları tarafından anlaşılmasından korkulmasıdır. Muğla'nın geleneksel kültürü içinde, acziyetini, muhtaçlığını başkalarına göstermeme önemli bir toplumsal davranış örneği olarak kabul edilmektedir. Bir diğer önemli etken de yaşlı olsa bile kırsal alandaki bireylerin hala küçük çaplı üretici olmaları ve bazı ihtiyaçlarını bu üretim sayesinde karşılayabilmeleridir.

Kent alanlarında yaşayan yaşlı bireylerin kırsal alandaki gibi kendi yiyeceklerini üretebileceği alanlar yoktur. Dayanışma kıra göre daha azdır. Parası olduğu müddetçe ihtiyaçlarını karşılayabilmekte, faturalarını ödeyebilmekte, alışverişini yapabilmekte, kirada ise kirasını verebilmektedir. Yalnız hissetme durumunun ise pek fark etmediği, yaşlılığın toplumsal değişmenin hızına paralel olarak bireylerde aynı oranda hissedildiği gözlemlenmiştir. 


\section{Sonuc}

Dünya toplumlarının ekonomik, siyasal ve kültürel olarak hızlı bir şekilde değişmesini sağlayan önemli olaylardan biri Sanayi Devrimi olmuştur. Sanayi Devrimi ile birlikte kırlardan kentlere yoğun göçler yaşanmaya başlamıştır ve bu göçler hala sürmekte, özellikle azgelişmiş ülkeler hızlı bir şekilde kentleşmeye devam etmektedir. Göçlerle birlikte kırsal alanlarda kalanlar çoğunlukla yaşlılar olmuş veya kalanlar da zaman geçtikçe yaşlanmıştır. Göç ve etkileriyle bilikte yaşlı bireylerin aile içindeki rolünün kökten değişmesi saygınlık ve otoritelerinin sarsılması, onların yalnız kalmalarına, bir süre sonra kendilerine yetemeyip bakıma muhtaç hale gelmelerine, üretemez halde olduklarından da yoksulluklarına neden olmuştur. Bu noktada, toplumsal alanda bir sorun olarak ortaya çıkan yaşlı yoksulluğu sosyal bir değişimin göstergesi olduğu gibi çözülmesi gereken bir sorun halini de almıştır.

Çalışmada bu sorunlar incelenmiş ve sorunlara ilişkin hipotezler geliştirilerek bireylere yöneltilmek üzere sorular hazırlanmıştır. İlk olarak, "yaşlanma, fiziksel ve zihinsel faaliyetlerin yavaşladı̆̆ ve zayıfladı̆̆ bir süreç olduğundan yaşlı bireylerin ekonomik gelirleri düşmektedir" hipotezinin doğrulandığı söylenebilir. Bireyler hayatları boyunca çalışıp yaşl1lıkta dinlenme evresine geçmekte ya da geçirilmektedirler. Yaşlılıkla birlikte bireyin üretici konumdan tüketici konuma geçmesi, birey ve toplumun karşılıklı bir etkileşim halinde olmasıyla gerçekleşmektedir. Yaşlanma ile birlikte gelen zihinsel ve fiziksel yeti kaybı bireylerin çalışma hayatından çekilerek dinlenme evresine geçmelerine neden olmaktadır. Toplumdaki bireyler açısından bakıldığında, işe ihtiyacı olan yaşlı bireyler işverenler tarafindan talep edilmeyen bir işgücü statüsüne girdiklerinden üretici konumunda bulunamamaktadırlar. Bireyin herhangi bir sosyal güvencesinin olmayışı yaşlılıkla birlikte yoksulluk sorunlarıyla da savaşmasına neden olmaktadır. Hayatlarını çalışarak geçiren bireyler için ise emeklilikle birlikte gelirlerinin düşmesi yaşam standartlarını düşürdügünden yaşlı bireyleri zorlu yaşam koşullarına sürükleyebilmektedir.

İkinci olarak, "yaşlllıkla birlikte gelen kendine yetememe durumu ve artan sağllk ihtiyaçları yaşlı bireylerin ekonomik olarak sorunlar yaşamasına neden olur” hipotezinin doğruluğu yapılan görüşmelerle tespit edilmiştir. Hatta bu konuda G7 isimli görüşmeci “... Eş̧imle birlikte yaşlyoruz sadece onun emekli maaşı var. Ben romatizma hastasıyım, eşim hem kalp hastası hem akciğer hastası hem de biraz zihinsel engeli var. aldiğı maaş 1000 lira ama ayın her günü hastanedeyiz. Hastane ve ilaç masraflarından bizim elimize geçen bir kuruş bile olmuyor. Yaşlandığımız için evde temizlik, yemek yapmakta zorlanıyoruz, temizlik için birini bulsak parasını veremeyiz, o yüzden çocuklar gelirse temizleniyor gelmezse temizlenmiyor ev ..." ifadesinde bulunmuştur.

Üçüncü olarak, "kır ve kentin ihtiyaçlarl farklıdır ve bu alanlarda yaşayan insanların ihtiyaç ve beklentileri farklı olduğundan, yoksulluk algılarında da farklıllk görü̈lür, buna göre kırda yaşayan yaşlılar daha düşük ekonomik gelire rağmen kendilerini yoksul olarak görmezken kentte yaşayan yaşlılar daha yüksek ekonomik gelire rağmen kendilerini yoksul olarak değerlendirir" hipotezinin doğruluğu saha araştırmasında yapılan görüşmeler ve gözlem sonucunda tespit edilmiştir. Araştırma kapsamında net bir çizgi ile kır kent ayrımı yapılmamıştır ancak merkez mahalleler ile dağ ve ova mahalleleri arasında bir kıyaslama yapıldığında yoksulluk algılarındaki farkın gözle görünür olduğu söylenebilir. Saha araştırması sürecinde anket içerisinde yer alan "et ve et ürünlerini ne sıklıkla tüketirsiniz?" sorusuna bir dağ mahallesinde yaşan yaşı bireyin, "bayramda dağıtan olursa yeriz" (A1) yanıtını vermesi ancak kendini yoksul hissetmemesi buna örnektir. Ancak aylık düzenli gelire sahip olup "kendinizi yoksul hissediyor musunuz?" sorusuna "idare etmeye çalışıyoruz" (A2) şeklinde ortalama bir yanıt vererek kendini yoksul hissettiğini göstermesi 
ise bir merkez mahallesine örnektir. Bu durum, yoksulluk kültürünün bireyler, mahalleler ve hatta toplumlar arası farklılık gösterdiğine bir örnektir.

Sonuç olarak; yaşam süresinin uzamasıyla birlikte yaşlanma ve yaşl1lık sosyal bir sorun halini almıştır. Yaşlılığın sorun olmasının temelinde yer alan en önemli faktörlerden biri de yoksulluktur. Fiziksel yeti kaybıyla birlikte ev içi temizliğin düzenli yapılmaması ya da hiç yapılamaması yaşlı bireylerin hijyenik olmayan bir ortamda sağlıksız bir şekilde yaşamalarına ve hastalanmalarına neden olabilmektedir. Bireyin ekonomik güvencesinin olmaması bireyi bir çok açıdan olumsuz yönde etkilemekte ve farklı sorunları da beraberinde getirmektedir. Ekonomik yetersizlikler bireyin sağlık sorunlarını, yalnızlığını, ayrımcılığa maruz kalmasını, toplumsal ve ekonomik alandan dışlanmasını tetikleyerek biyopsikososyal sorunlarla karşılaşmasına neden olabilmektedir.

Yaşlı yoksulluğunun ve beraberinde getirdiği sorunların giderilebilmesi için öncelikle var olan politikaların yetersizliği üzerinde çalışılmalı ve bu politikalar geliştirilmelidir. Bununla birlikte yaşlanan bireyin çalışma hayatından çekilip dinlenmesi gerektiği algısı dağıtılmalıdır. Çünkü bireyin emeklilikle birlikte düşen geliri yaşam kalitesini düşürürken, yetersizlik duygusu ve ekonomik-sosyal hayattan dışlanması yalnızlığa sürüklenmesine de sebep olabilmektedir. Bu noktada yaşlı bireylerin "eve kapanmaması" adına yaşlı bireylere uygun iş alanları oluşturulabilir. Bu sayede yaşlı birey hem gelirine katkı sağlayacak hem de yalnızlığa sürüklenerek psikolojik sorunlar yaşamaktan korunacaktır.

Yaşlılar için sosyal ve ekonomik yaşama daha fazla katılmalarını sağlayacak kamusal alanlar yaratılmalı ve yaşlıların, tecrübelerinden gençlerin daha fazla yararlanmasının önü açılmalıdır. Yaşlıların, özellikle kırsal alanlardaki yaşlıların sosyal sorumluluk projelerinin kapsamına daha fazla girmesi desteklenmeli, gençlerin ve çocukların yaşlılarla daha fazla zaman geçirmeleri sağlanmalıdır. Özellikle tarımsal ve hayvansal üretim yaparak küçük aile çiftliklerini devam ettirmeye çalışan yaşlıların desteklenmesi, üretim süreçlerine destek olmak için kentlerde yaşayan ortaöğretim ve üniversite öğrencilerinin, çeşitli yaz kampları kapsamında kırsal alanlara götürülmesi sağlanmalıdır.

Türkiye'de yaşlılara yönelik ekonomik destekler yetersizdir. Bu nedenle hem yaşlılık aylığı artırılmalı hem de emekli aylıkları yaş, yalnızlık durumu, cinsiyet, ev sahibi olup olmama, sağlık koşulları, yaşanılan yer, bakmakla yükümlü olduğu başka kişilerin olup olmaması gibi değişkenlere bağlı olarak kademeli bir şekilde artırılmalıdır.

Kırsalda yaşayan yaşlıların huzurevlerine veya yaşlı bakım merkezlerine gitme istekleri düşüktür ve oralara gittiklerine mutsuz olacakları açıktır. Bu nedenle kırsal alandaki yaşlılar sağlık sorunları veya engellerine bakılmaksızın evde bakım hizmetine dahil edilmeli, yakınlarının yanında kalarak bakılması teşvik edilmelidir. 


\section{KAYNAKÇA}

ADAMAN, F. ve KEYDER, Ç. (2006), "Türkiye'de Büyük Kentlerin Gecekondu ve Çöküntü Mahallelerinde Yaşanan Yoksulluk ve Sosyal Dışlanma”, Avrupa Komisyonu, Sosyal Dişlanma ile Mücadelede Mahalli Topluluk Eylem Programı 2002-2006.

AKTAN, C.C. ve VURAL, İ.Y. (2002), "Yoksulluk: Terminoloji, Temel Kavramlar ve Ölçüm Yöntemleri”, Yoksullukla Mücadele Stratejileri, (Ed.:Aktan, C. C.), Hak-Işs Konfederasyonu Yayınları, Ankara.

DANIŞ, M. Z. (2009). “Türkiye'de Yaşlı Nüfusun Yalnızlık ve Yoksulluk Durumları ve Sosyal Hizmet Uygulamaları Açısından Bazı Çıkarımlar", Toplum ve Sosyal Hizmet Dergisi, Cilt: 20 Say1: 1, s. 67-83.

GÜL, İ. I., KARAN, U. (2011), “Ayrımcılık Yasağı ve Temel Kavramlar”. Ayrımcllı Yasağl: Kavram, Hukuk, İzleme ve Belgeleme. (Ed.: Yeşiladalı, B., Ayata G.), Bilgi Üniversitesi Yayınlart. İstanbul.

GÜLlÜ, G. (2010). Gecekondulaşma, Gençlik ve Dindarlık -Kayseri Argıncık Örneği, (Yayımlanmamış Doktora Tezi) Erciyes Üniversitesi SBE, Kayseri.

KABASAKAL, M. (1998), "Yoksulluğu Önleme Stratejileri”, Türkiye'de Yoksulluk, SosyoEkonomik Politikalar ve Sivil Toplum, TESEV Yayınları, İstanbul.

KARADENIZ, O. ve ÖZTEPE, N. D. (2013). "Türkiye'de Yaşlı Yoksulluğu”, Çalışma ve Toplum Dergisi, Say1: 3, s. 77-102.

KAYA, Z. (2011), "Türkiye'de Yoksulluk Analizi: Bir Probit Model Uygulaması", (Yayınlanmamış Yüksek Lisans Tezi), Erzurum.

MARSHALL, G. (2003), “Sosyoloji Sözlüğü”, Bilim ve Sanat Yayınları, Ankara.

OKTIK, N. (edt.) (2008), “Türkiye'de Yoksulluk Çalışmaları”, Bağlam Yayınları, İstanbul.

OĞUZ, T. M. (2007), Yaşlılarda Görülen Biyolojik ve Sosyal Değişimler, (Yayınlanmamış Yüksek Lisans Tezi).Ankara Üniversitesi SBE, Ankara.

ÖZMETE, E., HABLEMITOĞLU, Ş. ve YILDIRIM, F. (2012), "Ankara'da Yaşlı Yoksulluğu: Ekonomik, Sosyal, Kültürel İhtiyaçların Analizi”, Ankara Üniversitesi Yaşlılık Çalışmaları Uygulama ve Araştırma Merkezi (Yaşam), Ankara.

ÖZTEPE, N.D. ve ULUTAŞ, Ç.Ü. (2013). "Bir Sosyal DIşlanma Biçimi Olarak Türkiye'de Refah Hizmetlerinden Dişlanma", Internatıonal Conference On Eurasıan Economies, Session 2B: Kalkinma.

ŞAHIN, T. (2009), Sosyal Dışlanma ve Yoksulluk Ilişskisi, (Yayınlanmış Uzmanlık Tezi), Sosyal Yardımlaşma ve Dayanışma Genel Müdürlüğü, Ankara,

ŞENSES, F. (2006), "Küreselleşmenin Öteki Yüzü: Yoksulluk”, İletişim Yayınları, İstanbul.

TARTANOĞLU, Ş. (2011). "Sosyal Dışlanma". Sosyal Politika. (Ed.: Tokol, A., Alper, Y.), Dora Basım, Bursa.

TÜİK. (2015a), "Adrese Dayalı Nüfus Kayıt Sistemine göre illerin toplam nüfusları ve 65 yaş ve üzeri nüfus oranları". https://biruni.tuik.gov.tr/medas/?kn=95\&locale=tr . Son erişim tarihi: 30 Ocak 2016. 
TÜİK. (2015b), “Adrese Dayalı Nüfus Kayıt Sistemine göre ilçeler, ilçelerdeki 65 yaş ve üzeri nüfus". https://biruni.tuik.gov.tr/medas/?kn=95\&locale=tr . Son erişim tarihi: 30 Ocak 2016.

TÜIKK. (2015). "Yalnız Yaşayan Yaşlı Bireylerin Oranları" http://www.tuik.gov.tr/basinOdasi/haberler/2016_63_20160524.pdf

TÜIKK. (2016), "Yalnız Yaşayan Yaşlı Bireylerin Oranları" http://www.tuik.gov.tr/PreHaberBultenleri.do?id=24644

TÜİK. (2016). "Senaryolara Göre Seçilmiş Yaş Grupları Nüfusları", http://www.tuik.gov.tr/PreTablo.do?alt_id=1027

YILDIRIM, M. (2011), “Ayrımc1lı". Sosyal Politika, (Ed.: Tokol, A., Alper, Y.). Dora Basim. Bursa.

UYAN, S. P., (2012), “Ayrımcılık Bağlamında Yoksulluk ve Sosyal Dışlanma. Ayrımcılık Çok Boyutlu Yaklaşımlar", (Der.: Çayır, K. Ve Ceytan, M.A.), İstanbul Bilgi Üniversitesi Yayınları, İstanbul.

UYSAL, Ş. (1993), "Yaşl1lık ve Sorunları" Psikoloji Semineri Ege Üniversitesi Edebiyat Fakültesi Yayını Sayı: 10, İzmir.

ZASTROW, C. (2013). Sosyal Hizmete Giriş, (Ed: Çiftçi, Ö. Çev.: Aykara, A. vd.). Nika Yayınevi. Ankara.

https://ankara.aile.gov.tr/duyurular/yenisosyal-ve-ekonomik-destek-yonetmeligi Erişim Tarihi: 18.07.2017

http://www.resmigazete.gov.tr/eskiler/2011/04/20110415-10.html Erişim Tarihi: 18.07.2017

Türkiye İşçi Sendikaları Konfederasyonu Haziran 2017 verileri 15.07.2017 tarihinde http://www.turkis.org.tr adresinden alınmıştır. 